\title{
OXIDATIVE STRESS IN PAINTERS EXPOSED TO LOW LEAD LEVELS
}

\author{
Imran Khan MOHAMMAD ${ }^{1}$, Abbas Ali MAHDI ${ }^{1}$, Aryapu RAVIRAJA², Islam NAJMUL ${ }^{3}$, \\ Ahmad IQBAL ${ }^{4}$, and Venkatesh THUPPIL ${ }^{2}$ \\ C.S.M. Medical University, Lucknow, Uttar Pradesh', National Referral Centre for Lead Poisoning in India, St. John's \\ Medical College, Koramangala, Bangalore, Karnataka², J.N. Medical College, Aligarh University, Aligarh ${ }^{3}$, Fibre \\ Toxicology Division, Indian Institute of Toxicology Research, Lucknow ${ }^{4}$, India
}

Received in May 2008

Accepted in July 2008

\begin{abstract}
Lead toxicity is a public health problem particularly to the children and to occupationally exposed adults. Evidence is mounting successively regarding the adverse health effects of lead at low levels. This study was undertaken to assess the antioxidant status of lead-exposed residential and commercial painters of Lucknow city in Uttar Pradesh, India.

Thirty-five painters aged 20 to 50 years who had blood lead levels $\leq 400 \mu \mathrm{g} \mathrm{L}^{-1}$ were selected for the study from a population of 56 male painters initially screened for blood lead. The control group included an equal number of subjects of the same age group without any occupational exposure to lead.

We studied the association between low lead level exposure and antioxidant status and found that blood lead levels in painters were approximately seven times as high as in controls [(219.2 \pm 61.9$) \mu \mathrm{g} \mathrm{L}^{-1}$ vs. (30.6 \pm 10.1$) \mu \mathrm{g} \mathrm{L}^{-1}$, respectively]. Among the biomarkers of lead toxicity a significant decrease in the level of delta-aminolevulinic acid dehydratase $\left[(9.13 \pm 4.62) \mathrm{UL}^{-1}\right.$ vs. $\left.(39.38 \pm 5.05) \mathrm{UL}^{-1}\right]$ and an increase in the level of zinc protoporphyrin [(187.9 \pm 49.8$) \mu \mathrm{g} \mathrm{L}^{-1} \mathrm{vs}$. $\left.(26.4 \pm 5.5) \mu \mathrm{g} \mathrm{L}^{-1}\right]$ were observed in painters compared to controls. Among antioxidant enzymes, painters showed a significant decrease in catalase $\left[(56.77 \pm 11.11) \mathrm{UL}^{-1}\right.$ vs. $\left.(230.30 \pm 42.55) \mathrm{UL}^{-1}\right]$ and superoxide dismutase $[(0.64 \pm 0.19) \mathrm{UL}-1 \mathrm{vs.}$ $\left.(2.68 \pm 0.62) \mathrm{UL}^{-1}\right]$ compared to controls. Lipid peroxidation was monitored by measuring thiobarbituric acid reactive substances (TBARS) that were expressed in terms of malondialdehyde (MDA) equivalents. Concentration of MDA in plasma was higher in painters than in controls $\left[(7.48 \pm 1.31) \mathrm{nmol} \mathrm{mL}^{-1} \mathrm{vs}\right.$. $(3.08 \pm 0.56) \mathrm{nmol} \mathrm{mL}^{-1}$. Significant changes were also observed in reduced and oxidised glutathione levels. The strong association between blood lead levels and oxidative stress markers in this population suggests that oxidative stress should be considered in the pathogenesis of lead-related diseases among people with low level environmental exposure to lead.
\end{abstract}

KEY WORDS: blood lead, catalase, lead toxicity, lipid peroxidation, paints, superoxide dismutase, zinc protoporphyrin

Lead, used by mankind for over 6000 years, is one of the most widely scattered toxic metals in the environment today. It does not have any useful functions in the human body, and produces only harmful effects once it enters the body either by ingestion, inhalation, or by dermal contact (organic lead). Although the permissible limit for blood lead in workers exposed to lead set by the Occupational Safety and Health Administration (OSHA) is $1.93 \mu \mathrm{mol} \mathrm{L}^{-1}$ $\left(400 \mu \mathrm{g} \mathrm{L}^{-1}\right)$ and the maximum allowable blood lead level is $2.41 \mu \mathrm{mol} \mathrm{L}^{-1}\left(500 \mu \mathrm{g} \mathrm{L}^{-1}\right)$ (1), adverse health effects below this standard limit have been reported.

Lead is related to a broad range of physiological, biochemical, and behavioural dysfunctions (2). Lead potentially induces oxidative stress, and evidence to support the role of oxidative stress in 
the pathophysiology of lead toxicity is accumulating $(3,4)$. Several epidemiological studies among workers with high occupational lead exposure have reported positive association between lead exposure and oxidative stress markers (5-7). However recent epidemiological studies have reported that even at low level, lead has a graded association with several ill health outcomes such as peripheral artery disease, hypertension, neurodegenerative disease, kidney disease, and cognitive impairment (8-13). Although both moderate and sub-clinical effects of occupational lead poisoning are common in many countries of the world, occupational exposure is entirely unregulated in developing countries like India, and little monitoring has been conducted in developed countries (14). In the 18th, 19th, and 20th century the worst outbreaks of lead poisoning were occupational in origin. Workers were mainly exposed to lead either by inhalation of fine lead dust and fumes or by ingestion of lead particles.

Lead is widely used in various paints because of its anticorrosive properties and ability to hold pigments together. Recently, Alphen et al. (15) reported that $10 \%$ of lead metal consumed in India was used for manufacturing paints. A recent study by Scott Clark et al. (16) reported that $100 \%$ of Indian paints contained lead at levels above the US limit of $0.06 \%$. Painters are continuously exposed to lead-containing paints as well as to an extensive variety of hazardous substances like organic solvents and residual plastic monomers. In this study we assessed the blood lead levels (BLL) in painters using commercially available Indian paints and occasionally gasoline or thinners as solvents. Paints were applied using brushes or by aerosol spraying, and were removed by sandblasting and scraping off the surfaces previously coated with paint. Both tasks were performed without proper protection (gloves and mask). We decided to select painters with low BLL ( $\left.\leq 400 \mu \mathrm{g} \mathrm{L}^{-1}\right)$ and to see if there was any association with oxidative stress markers.

\section{SUBJECTS AND METHODS}

\section{Study population}

For the study, the ethical clearance was obtained from King George Medical University, Lucknow, India. A written consent was obtained from the subjects, who had been informed of the importance of the study in their local language. Residential and commercial painters were selected and recruited on the basis of routine surveillance data of those who were engaged with local contractors in Lucknow. Initially the study included 56 male painters aged between 20 and 50 years, who were screened for blood lead levels. Of them 35 painters with BLL $\leq 400 \mu \mathrm{g} \mathrm{L}^{-1}$ were selected to continue in our study. These painters had been painting houses eight to nine hours a day for five to 10 years. The control group included an equal number of subjects of the same age with no occupational exposure to lead, who were normal healthy blood donors and lived in the vicinity. We used a questionnaire to obtain information on occupation and medical history, job description, socio-economic status, and lifestyle of both groups. Subjects having a previous history of metabolic diseases such as diabetes mellitus, hypertension, malignancy, heart disease, infectious diseases like arthritis and tuberculosis, and endocrinal disorders and conditions known to generate oxidative stress were excluded from the study.

\section{Blood collection}

Taking all aseptic precautions, an expertphlebotomist collected $6 \mathrm{~mL}$ of total venous blood from each subject in dipotassium ethylenediaminetetraacetic acid (EDTA) vacutainers (BD biosciences. USA). Two millilitres were used to estimate lead, zinc protoporphyrin (ZPP), and delta-aminolevulinic acid dehydratase (delta-ALAD). The other $4 \mathrm{~mL}$ were centrifuged at $3000 \mathrm{rpm}$ for 15 minutes to separate plasma, while the remaining red blood cells were lysed by mixing with normal saline. Both plasma and the red blood cell lysate were used to determine superoxide dismutase (SOD), catalase (CAT), reduced glutathione (GSH), oxidised glutathione (GSSG), and thiobarbituric acid reactive substances (TBARS).

\section{Analytical methods}

Blood lead levels were determined using a graphite furnace atomic absorption spectrometer (Varian Australia Pty, Victoria, Australia) (17). The instrument was calibrated using aqueous standards of various lead concentrations [(100 to 400) $\mu \mathrm{g} \mathrm{L}^{-1}$ ]. Blood delta-ALAD activity was measured following the European standardized method (18). ZPP levels were directly measured in whole blood using a haematofluorometer (19). For the determination of GSH and GSSG, 5,5'-dithio-bis(2-nitrobenzoic acid) 
(DTNB) was used as described by Ellman (20). Plasma levels of lipid peroxides were determined as TBARS according to the method of Ohkawa et al. (21). Red blood cells were lysed with cold triple distilled water (TDW) and the haemolysate was obtained. SOD activity was also determined spectrophotometrically according to the method of McCord and Fridovich (22). Catalase activity in the haemolysate was determined spectrophotometrically using hydrogen peroxide $\left(\mathrm{H}_{2} \mathrm{O}_{2}\right)$ as a substrate (23). Total proteins of red blood cell samples were determined using the method of Lowry et al. (24).

\section{Statistical Analysis}

Student's t-test was used to analyse the significance of the mean differences between control subjects and lead-exposed painters. Relative association among the parameters of control subjects and leadexposed painters were determined separately by Pearson's correlation coefficient (r). Linear regression analysis was performed to determine the strength of the relationship between blood lead levels and other significantly correlated parameters of leadexposed painters after transforming the data by log transformation.

\section{RESULTS}

The results of our findings are shown in Table 1. Blood lead levels were significantly higher in painters than in controls. The activities of antioxidant enzymes SOD and CAT were significantly lower in painters $(p<0.01)$ than in controls. Lipid peroxidation (TBARS) was significantly higher in painters than in controls. Among the biomarkers of lead toxicity, a significant decrease in delta-ALAD activity and a significant increase in the level of ZPP was observed in painters. In addition, significant differences in GSH and GSSG levels were observed between the exposed subjects and controls.

Table 2 shows the strength of the relationship between blood lead levels and biomarkers of lead toxicity, including antioxidant enzymes. The most significant negative correlation of blood lead level was with delta-ALAD $(r=-0.71)$, followed by CAT $(r=$ -0.39). Positive correlations of blood lead levels were the highest with TBARS $(r=+0.34)$, followed by ZPP $(\mathrm{r}=+0.30)$.

Figure 1 shows significant regression between blood lead levels and biomarkers of lead toxicity (deltaALAD and ZPP), TBARS and CAT.

\section{DISCUSSION}

Lead is widely used in preparation of paints due to its anticorrosive properties. Alphen et al. has reported that $10 \%$ of the total lead consumed in India is said to be used in paint manufacture (15). Recently Scott Clark et al. have also reported that most of the Indian Paints used today are known to contain lead in excess of the US permissible limit of $0.06 \%$ (16). Painters who spend a considerable amount of time in either removing old paint from buildings due for renovation or in painting new buildings are at high

Table 1 Values of parameters (mean \pm SD) and their comparison by Student's t-test

\begin{tabular}{|c|c|c|c|}
\hline Parameters & Control $(n=35)$ & Painters $(n=35)$ & t-test \\
\hline Age / year & $32.85 \pm 5.82$ & $32.14 \pm 6.11$ & $0.45^{\mathrm{NS}}$ \\
\hline Exposure / months & - & $126.08 \pm 49.53$ & - \\
\hline BLLs / $\mu \mathrm{g} \mathrm{L}^{-1}$ & $30.6 \pm 10.1$ & $219.2 \pm 61.9$ & $22.85^{* *}$ \\
\hline delta-ALAD / $\mathrm{UL}^{-1}$ & $39.38 \pm 5.05$ & $9.13 \pm 4.62$ & $11.67 * *$ \\
\hline $\mathrm{ZPP} / \mu \mathrm{g} \mathrm{L}^{-1}$ & $26.4 \pm 5.5$ & $187.9 \pm 49.8$ & $27.58^{* *}$ \\
\hline $\mathrm{GSH} / \mu \mathrm{mol} \mathrm{L}-1$ & $580.92 \pm 68.96$ & $418.55 \pm 58.58$ & $9.37 * *$ \\
\hline GSSG / $\mu \mathrm{mol} \mathrm{L}^{-1}$ & $154.75 \pm 47.68$ & $232.17 \pm 56.48$ & $5.45^{* *}$ \\
\hline TBARS as MDA / $\mathrm{nmol} \mathrm{mL}^{-1}$ & $3.08 \pm 0.56$ & $7.48 \pm 1.31$ & $17.67 * *$ \\
\hline SOD / U mg $\mathrm{mg}^{-1}$ of protein & $2.68 \pm 0.62$ & $0.64 \pm 0.19$ & $16.61^{* *}$ \\
\hline CAT / U mg $\mathrm{mg}^{-1}$ of protein & $230.30 \pm 42.53$ & $56.77 \pm 11.21$ & $24.98 * *$ \\
\hline
\end{tabular}

NS - not significant $(p>0.05)$

** Significant $(p<0.01)$ 


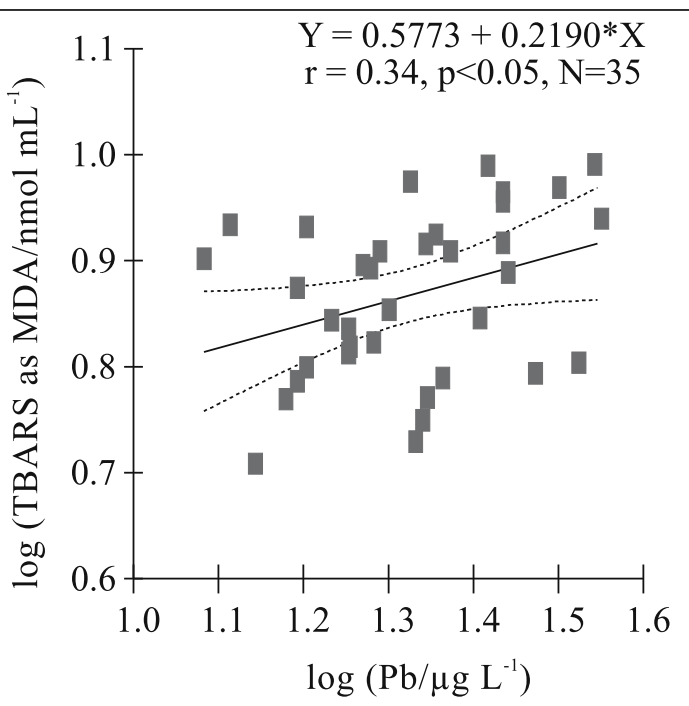

(A)

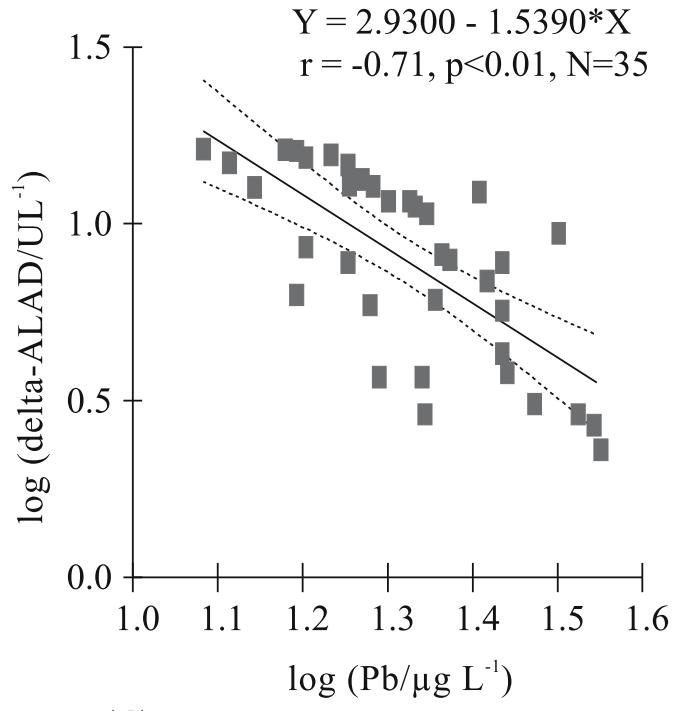

(C)

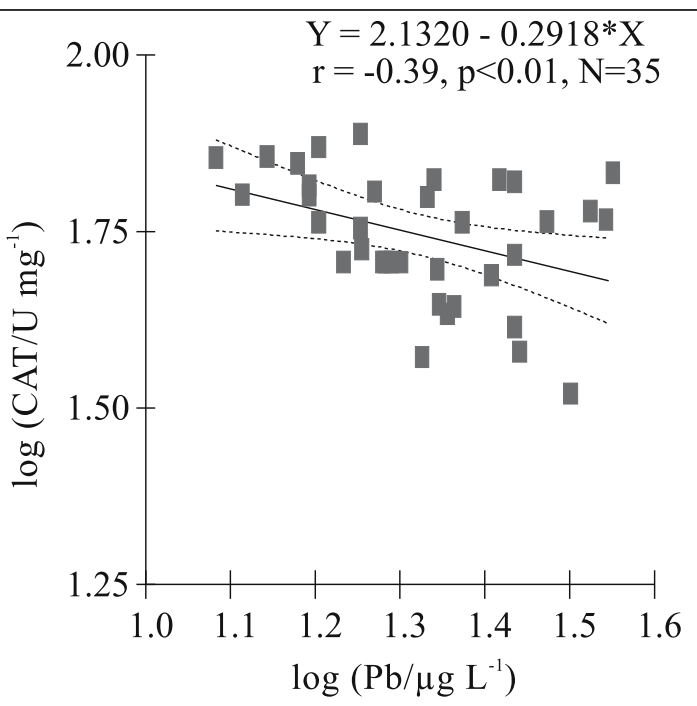

(B)

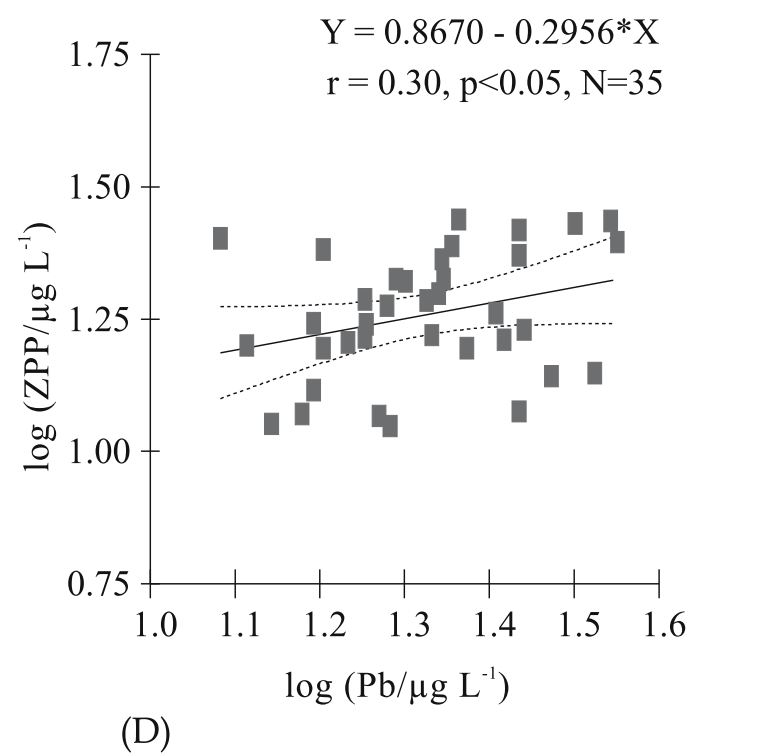

Figure 1 Correlation and regression between blood lead levels in painters and the parameters of oxidative stress (A-B) and lead toxicity (C-D)

Table 2 Coefficient of correlation (r) between determined parameters in lead-exposed painters

\begin{tabular}{lcccccccc}
\hline Parameters & BLLs & delta-ALAD & ZPP & GSH & GSSG & TBARS & SOD & CAT \\
\hline BLLs & 1.00 & & & & & & & \\
delta-ALAD & $-0.71^{* *}$ & 1.00 & & & & & & \\
ZPP & $0.30^{*}$ & -0.19 & 1.00 & & & & & \\
GSH & -0.11 & -0.06 & -0.03 & 1.00 & & & & \\
GSSG & 0.23 & -0.03 & 0.21 & 0.03 & 1.00 & & & \\
TBARS & $0.34^{*}$ & -0.19 & $0.48^{* *}$ & 0.05 & $0.28^{*}$ & 1.00 & & \\
SOD & -0.18 & -0.06 & $-0.47^{* *}$ & 0.11 & -0.03 & -0.03 & 1.00 & \\
CAT & $-0.39^{* *}$ & 0.13 & $-0.30^{*}$ & -0.11 & -0.13 & -0.25 & $0.31^{*}$ & 1.00 \\
\hline
\end{tabular}

"Significant $(p<0.05)$

** Highly significant $(p<0.01)$ 
risk of lead toxicity. The results of our study clearly demonstrate that painters have higher blood lead levels than controls. Our study is in agreement with other previous reports on blood lead levels in Indian painters $(25,26)$.

Numerous recent evidence supports the role of oxidative stress in the pathophysiology of lead toxicity (27-28). Lead causes oxidative stress by inducing the generation of reactive oxygen species and by reducing the antioxidant cell defence systems by depleting glutathione, by inhibiting sulfhydryl-dependent enzymes, by interfering with some essential metals needed for antioxidant enzyme activities, and/or by increasing cell susceptibility to oxidative attack by altering the membrane integrity and fatty acid composition (4, 29, 30). Consequently, the resulting impaired oxidant/antioxidant balance can be partially responsible for the effects of lead. Most of the epidemiological studies report a positive association between blood lead levels and oxidative stress markers only in workers with high occupational exposure. The association between oxidative stress and low-level lead exposure is still inconclusive. However, Lee et al. have recently reported oxidative stress even at low levels of lead exposure (12).

We too have observed a significant difference in selected oxidative parameters between painters and controls, which suggests that oxidative damage can occur even at low blood lead levels. The strong correlation observed between blood lead concentration and oxidative stress markers such as CAT, SOD, and lipid peroxidation products (Table 2 ) suggests that lead may have induced oxidative damage in these painters.

It is well known that lead can cause anaemia through different pathways such as by decreasing the red blood cell survival or by inhibiting haem synthesis (31). Lead decreases the life span of red blood cells by inhibiting sodium-potassium ATPase and pyrimidine 5' nucleotidase, which impairs red blood cell membrane stability by altering energy metabolism (32), and it decreases haem synthesis by inhibiting some of the key enzymes of the biosynthetic pathway such as delta-ALAD, ferrochelatase, and coproporphyrinogen oxidase (33)

In our study, we have observed a significant decrease and a negative correlation between deltaALAD and blood lead (Table 2). We also observed a significant increase and a positive correlation between ZPP and blood lead levels in painters (Table 1), which points to the inhibition of haem synthesis even at low blood lead levels.
Our study corroborates the reports by Austrin et al., who found a $50 \%$ inhibition of delta-ALAD activity at BLL of $150 \mu \mathrm{g} \mathrm{L}^{-1}$ (34), and recently by Sakai and Morita (35) found that the threshold of blood lead for delta-ALAD inhibition was extremely low (approximately $50 \mu \mathrm{g} \mathrm{L}^{-1}$ ).

Our study shows an increase in ZPP levels because lead is known to inhibit the activity of ferrochelatase which catalyses the last step of the haem synthesis, where normally it incorporates iron into protoporphyrin IX to produce the haem. In lead toxicity, zinc is incorporated into protoporphyrin instead of iron, resulting in the production and accumulation of zinc protoporphyrin (36). However, in the abundance of haemoglobin $(\mathrm{Hb})$, increased ZPP is relatively harmless even in a serious case of lead poisoning, because it may constitute less than $1 \%$ of the total $\mathrm{Hb}$ production (37).

Lead is known to generate free radicals at different levels. At the first level, the inhibition of delta ALAD by lead results in accumulation of delta aminolevulinic acid that can rapidly oxidise to free radicals such as superoxide anion, hydroxyl radical, and hydrogen peroxide (38). At the second level, lead can stimulate ferrous ion-initiated membrane lipid peroxidation (39, 40). Several antioxidant molecules such as glutathione (GSH) and glutathione disulphide (GSSG) and antioxidant enzymes such as SOD, CAT, glutathione peroxidase (GPx), and glutathione reductase (GR) are the most common parameters used to evaluate leadinduced oxidative damage $(29,41,42)$. GSH plays a pivotal role in the protection of cells against oxidative stress. It can act as a non-enzymatic antioxidant by direct interaction of the $\mathrm{SH}$ group with $\mathrm{ROS}$, or it can be involved in the enzymatic detoxification reactions for ROS as a cofactor (29). Many studies have shown a decrease in GSH levels during lead toxicity $(40,42)$. Similarly, in our study we also observed a significant depletion of GSH in painters compared to controls. A significant change was also observed in the oxidised form of GSH, i.e. GSSG. However, both reduced and oxidised forms of GSH fail to show strong negative and positive correlation with blood lead levels.

CAT and SOD are metalloproteins and accomplish their antioxidant functions by enzymatically detoxifying the peroxides $\left(\mathrm{OH}, \mathrm{H}_{2} \mathrm{O}_{2}\right)$ and superoxide anion. CAT decomposes $\mathrm{H}_{2} \mathrm{O}_{2}$ to $\mathrm{H}_{2} \mathrm{O}$ and $\mathrm{O}_{2}$ whereas superoxide dismutase dismutates superoxide into $\mathrm{H}_{2} \mathrm{O}_{2}$, and needs copper and zinc for its activity. Various reports regarding influence of lead on SOD and CAT activities 
have given divergent results. Some studies showed decreased activities of SOD and CAT $(44,45)$, and others showed increased activities $(46,47)$. In our study we observed a significant decrease in CAT and SOD activities in painters compared to controls (Table 1). Our correlation analysis has also showed a strong negative correlation between blood lead and CAT $(r=-0.39, p<0.01)$, suggesting a strong relationship between increased blood lead levels and decreased activities of antioxidant enzymes in painters compared to controls.

The lower activities of CAT and SOD may partly be explained by the interaction between lead and essential metals such as copper, zinc, and iron. Copper and zinc are essential cofactors for SOD, whereas CAT also contains haem as the prosthetic group, the biosynthesis of which is inhibited by lead $(48,49)$.

Lead is known to have toxic effects on membrane function (50). It alters the red blood cell membrane in particular, because red blood cells have a high affinity for lead and are more vulnerable to oxidative damage than any other cells (51). We also observed a significantly elevated lipid peroxide levels in the plasma measured as TBARS (Table 1). There was a positive correlation $(r=+0.34)$ between blood lead levels and TBARS in painters compared to controls. Similar reports were also reported by Patil et al, in spray painters of western Maharastra, India (26).

Finally, our study shows that painters are continuously exposed to the toxic effects of lead due to its high percentage in commercially available paints. Our study clearly suggests that oxidative stress occurs even at this low level of exposure. It is an important component of several disease outcomes such as hypertension, peripheral artery disease, kidney diseases, and cognitive impairment.

\section{CONCLUSION}

This study has found strong evidence of oxidative stress at blood lead levels substantially lower than those defined as dangerous by OSHA and CDC. However, it is still unclear how altered antioxidant status affects the risk of adverse clinical outcomes. More studies are needed to clarify the relationship between a variety of health outcomes resulting from oxidative stress and low lead levels. Since the use of lead is totally unregulated in Indian paints, it is necessary to limit its use, by adopting the US limit of $0.06 \%$. The potential risk of lead poisoning will still persist until safety measures are taken by the employees and are monitored by social groups and government agencies.

\section{Acknowledgement}

The authors wish to thank Dr Farzana Mahdi (Director, Academics - ERA's Lucknow Medical College) for providing the research facility and Dr Ramesh Chander (Emeritus scientist, Dept. of Biochemistry C.S.M. Medical University) for the careful reading of the manuscript. We also thank M.P.S. Negi for statistical analysis.

\section{REFERENCES}

1. Occupational Safety and Health Administration (OSHA). Employee Standard Summary - 1910.1025 App B [displayed 6 January 2008]. Available at http:// www.laborcommission.utah.gov/UOSH/Outreach/ ConstructionCD/www.osha.gov/pls/oshaweb/ standards-10032.htm.

2. Courtois E, Marques M, Barrientos A. Lead-induced down-regulation of soluble guanylate cyclase in isolated rat aortic segments mediated by reactive oxygen species and cyclo-oxygenase-2. J Am Soc Nephrol .2003;14:1464-70.

3. Ercal N, Neal R, Treeratphan P, Lutz PM, Hammond TC, Dennery PA, Spitz DR. A role for oxidative stress in suppressing serum immunoglobulin levels in leadexposed Fisher 344 rats. Arch Environ Contam Toxicol 2000;39:251-6.

4. Farmand F, Ehdaie A, Roberts CK, Sindhu RK. Leadinduced dysregulation of superoxide dismutase, catalase, glutathione peroxidase, and guanylate cyclase. Environ Res 2005;98:33-9.

5. Costa CA, Trivelato GC, Pinto AMP, Bechara EJH. Correlation between plasma 5 -aminolevulinic acid concentrations and indicators of oxidative stress in lead-exposed workers. Clin Chem 1997; 43:1196202.

6. Gurer-Orhan H, Sabir HU, Ozgunes H. Correlation between clinical indicator of lead poisoning and oxidative stress parameters in controls and lead exposed workers. Toxicology 2004; 195:147-54.

7. Kasperczyk S, Birkner E, Kasperczyk A, Kasperczyk J. Lipids, lipid peroxidation and 7-ketocholesterol in workers exposed to lead. Hum Exp Toxicol 2005; 24:287-95.

8. Muntener P, He J, Vupputuri S, Coresh J, Batuman V. Blood lead and chronic kidney disease in the general United States population: results from NHANES III. Kidney Int 2003; 63:1044-50.

9. Nash D, Magder L, Lustberg M, Sherwin RW, Rubin RJ, Kaufmann RB. Blood lead, blood pressure, and 
hypertension in perimenopausal and postmenopausal women. JAMA 2003; 289:1523-32.

10. Navas-Acien A, Selvin E, Sharrett AR, Calderon-Aranda E, Silbergeld E, Gaullar E. Lead, cadmium, smoking, and increased risk of peripheral arterial disease. Circulation 2004; 109:1196-201.

11. Ekong EB, Jaar BG,Weaver VM. Lead-related nephrotoxicity: a review of epidemiologic evidence. Kindey Int 2006; 70:2074-84.

12. Lee DH, Lim JS, Song K, Boo Y, Jacobs Jr DR. Graded association of blood lead and urinary cadmium concentrations with oxidative stress related markers in the U.S. population: results from the third national health and nutrition examination survey. Environ Health Perspect 2006; 114:350-4.

13. Menke A, Muntner P, Batuman P, Silbergeld EK, Guallar E. Blood lead below $0.48 \mu \mathrm{mol} / \mathrm{L}(100 \mu \mathrm{gL}-1)$ and mortality among US adults. Circulation 2006; 114:1388-94.

14. Verrula GR and Noah, PK. Clinical manifestations of childhood lead poisoning. Trop Med Hyg 1990; 93:1707.

15. Alphen MV. Lead in paints and water in India. In: Proceedings of the International Conference on Lead Poisoning Prevention and Treatment; 8-10 Feb 1999; Bangalore, India. Bangalore: The George Foundation; 1999. p. 265-72.

16. Clark CS, Rampal KG, Thuppil V, Chen CK, Clark R, Roda S. The lead content of currently available new residential paint in several Asian countries. Environ Res 2006; 102:9-12.

17. Benzo ZA, Fraile R, Carrison N, Loreto D. Determination of lead in whole blood by electrothermal atomization atomic absorption spectrometry using tube and platform atomizers and dilution with Triton X-100. J Anal Atom Spectrom 1989; 4:397-400.

18. Berlin A, Schaller KH. European standardized method for the determination of delta aminolevulinic acid dehydratase activity in blood. Z Klin Chem Klin Biochem 1974; 12:389-90.

19. Blumberg WE, Eisinger J, Lamola AA, Zuckeman DM. The hematofluorometer. Clin Chem 1977; 23:270-4.

20. Ellman GL. Tissue sulfhydryl groups. Arch Biochem 1959; 82:70-7.

21. Ohkawa H, Oshiba N, Yagi K. Assay of lipid peroxides in animal tissue by thiobarbutyric acid reaction. Anat Biochem 1979; 95:351-8.

22. Mc Cord JM, Fridovich I. Superoxide dismutase: An enzymic function for erythrocuprein (hemocuprein). J Biol Chem 1969; 244:6049-55.

23. Aebi H. Catalase in vitro. Methods Enzymol 1984; 105:121-6.

24. Lowry OH, Rosebrough NJ, Farr AL, Randell RJ. Protein measurement with the Folin phenol reagent. J Biol Chem 1951; 193:265-75.

25. Rao GM, Shetty BV, Sudha K. Effect of lead on oxidant: antioxidant balance in painters. Clin Chim Acta 2006; 367:209-10

26. Patil JA, Bhagwat RV, Patil AJ, Dongre NN, Ambekar GJ, Das KK. Biochemical aspects of lead exposure and toxicity in spray painters of WesternMaharashtra (India). J Environ Health Res 2007; 6:101-10.

27. Stohs SJ, Bagchi D. Oxidative mechanisms in the toxicity of metal ions. Free Radic Biol Med 1995; 18:321-36.

28. Ercal N, Gurer-Orhan H, Aykin-Burns N. Toxic metals and oxidative stress part I: mechanisms involved in metal induced oxidative damage. Curr Top Med Chem 2001; 1:529-39.

29. Ding Y, Gonick HC, Vaziri ND. Lead promotes hydroxyl radical generation and lipid peroxidation in cultured aortic endothelial cells. Am J Hypertens 2000; 13:5525.

30. Cabell L, Ferguson C, Luginbill D, Kern M, Weingart A, Audesirk G. Differential induction of heme oxygenase and other stress proteins in cultured hippocampal astrocytes and neurons by inorganic lead. Toxicol Appl Pharmacol 2004; 98:49-60.

31. Graziano JH, Slavkovic V, Factor-Litvak P, Popovac D, Ahmedi X, Mehmeti A. Depressed serum erythropoietin in pregnant women with elevated blood lead. Arch Environ Health 1991; 46:347-50.

32. Pagila DE, Valentine WN, Dahlger JG. Effects of low level lead exposure on pyrimidine-5' nucleotidase and other erythrocytes enzymes. J Clin Invest 1976; 56:1164-9.

33. Piomelli S. Childhood lead poisoning. Pediatr Clin $\mathrm{N}$ Am 2002; 49:1285-304.

34. Austrin KH, Bishap DF, Wetmur JG, Kaul BC, Davidow B, Desnick RJ. Aminolevulinic acid dehydratase isozymes and lead toxicity. Ann NY Acad Sci 1987; 514:23-9.

35. Sakai T, Morita Y. Delta-aminolevulinic acid in plasma or whole blood as a sensitive indicator of lead effects, and its relation to the other heme-related parameters. Int Arch Occup Environ Health 1996; 68:126-32.

36. Marcus AH, Schwartz J. Dose-response curves for erythrocyte porphyrin vs. Blood lead, effects of iron status. Environ Res 1987; 44:221-7.

37. Onalaja VO, Claudio L. Genetic susceptibility to lead poisoning. Environ Health Perspect 2000; 108:23-8.

38. Gurer-Orhan H, Sabir HU, Ozgunes H. Correlation between clinical indicator of lead poisoning and oxidative stress parameters in controls and lead exposed workers. Toxicology 2004; 195:147-54.

39. Adonaylo VN, Oteiza PI. $\mathrm{Pb}^{2+}$ promotes lipid peroxidation and alteration in membrane physical properties. Toxicology 1999; 132:19-32.

40. Bechara EJH. Lead poisoning and oxidative stress. Free Radic Biol Med 2004; 36(Suppl 1):S22.

41. Hsu PC, Hsu CC, Liu MY, Chen LY, Guo YL. Leadinduced changes in spermatozoa function and 
metabolism. J Toxicol Environ Health 1998; 55:4564.

42. Patra RC, Swarup D, Dwidedi SK. Antioxidant effects of $\alpha$-tocopherol, ascorbic acid and L-methionine on lead-induced oxidative stress of the liver, kidney and brain in rats. Toxicology 2001; 162:81-8.

43. Gurer H, Ozgunes H, Neal R, Spitz DR, Ercal N. Antioxidant effects of $\mathrm{N}$-acetylcysteine and succimer in red blood cells from lead exposed rats. Toxicology 1998; 128:181-9.

44. Ito Y, Niiya Y, Kurita H, Shima S, Sarai S. Serum lipid peroxide level and blood superoxide dismutase activity in workers with occupational exposure to lead. Int Arch Occup Environ Health 1985; 56:119-27.

45. Valenzuela A, Lefauconnicer JM, Chaudiere J, Bourre JM. Effects of lead acetate on cerebral glutathione peroxidase and catalase in the suckling rat. Neurotoxicology 1989; 10:63-9.

46. Adler AJ, Barth RH, Berlyne GM. Effect of lead on oxygen free radical metabolism: inhibition of superoxide dismutase activity. Trace Elem Med 1993; 10:93-6.
47. Ahamed M, Verma S, Kumar A, Siddiqui MKJ. Delta-aminolevulinic acid dehydratase inhibition and oxidative stress in relation to blood lead among urban adolescents. Human Exp Toxicol 2006; 25:547-53.

48. Mylroie AA, Collins H, Umbles C, Kyle J. Erythrocyte superoxide dismutase activity and other parameters of copper status in rat ingesting lead acetate. Toxicol Appl Pharmacol 1986; 82:512-20.

49. Patil AJ, Bhagwat VR, Patil JA, Dongre NN, Ambekar JG, Jailkhani R, Das KK. Effect of lead (Pb) exposure on the activity of superoxide dismutase and catalase in battery manufacturing workers (BMW) of western Maharashtra (India) with reference to heme biosynthesis. Int $\mathrm{J}$ Environ Res Public Health 2006; 3:329-37.

50. Donaldson WE, Knowles SO. Is lead toxicosis a reflection of altered fatty acid composition of membrane? Comp Biochem Physiol C 1993; 104:377-9.

51. Leggett RW. An age specific kinetic model of lead metabolism in humans. Environ Health Perspect 1993; 101:598-616. 


\section{Sažetak}

\section{OKSIDACIJSKI STRES U LAKIRERA IZLOŽENIH NISKIM RAZINAMA OLOVA}

Toksičnost olova javnozdravstveni je problem, napose u djece i odraslih osoba koje su im izložene profesionalno. Sve je više dokaza o štetnom djelovanju olova pri niskim razinama. Svrha je ovog ispitivanja bila procijeniti antioksidacijski status u lakirera iz grada Lucknowa u indijskoj pokrajini Uttar Pradesh. Iz skupine od 56 muškaraca lakirera u dobi od 20 do 50 godina s pozitivnim početnim nalazima olova u krvi, za ispitivanje su izabrana 35-orica čije su razine iznosile $\leq 400 \mu \mathrm{g} \mathrm{L}^{-1}$. Izabran je i jednaki broj kontrolnih ispitanika iz iste dobne skupine, koji nisu bili profesionalno izloženi olovu.

Ispitana je povezanost između izloženosti niskim razinama olova i antioksidacijskoga stanja te je utvrđeno da su razine olova u krvi lakirera $\left[(219,2 \pm 61,9) \mu \mathrm{g} \mathrm{L}^{-1}\right]$ bile oko sedam puta više negoli u kontrolnih ispitanika $\left[(30,6 \pm 10,1) \mu \mathrm{g} \mathrm{L}^{-1}\right]$. Od biopokazatelja toksičnosti olova u lakirera je zamijećen značajan pad razina deltaALAD $\left[(9,13 \pm 4,62) \mathrm{UL}^{-1}\right.$ prema $\left.(39,38 \pm 5,05) \mathrm{UL}^{-1}\right]$ te rast razina cinkova protoporfirina $[(187,9 \pm 49,8)$ $\mu \mathrm{g} \mathrm{L}^{-1}$ prema $\left.(26,4 \pm 5,5) \mu \mathrm{g} \mathrm{L}^{-1}\right] \mathrm{u}$ odnosu na kontrolne ispitanike. Od antioksidacijskih enzima u lakirera je značajno pala aktivnost katalaze $\left[(56,77 \pm 11,11) \mathrm{UL}^{-1}\right.$ prema $\left.(230,30 \pm 42,55) \mathrm{UL}^{-1}\right]$ i superoksid dismutaze $\left[(0,64 \pm 0.19) \mathrm{UL}^{-1}\right.$ prema $\left.(2,68 \pm 0,62) \mathrm{UL}^{-1}\right] \mathrm{u}$ odnosu na kontrolu, dok je produkt lipidne peroksidacije u plazmi (izv. thiobarbituric acid reactive substances, TBARS) izražen kao koncentracija malondialdehida (MDA) porastao $\left[(7,48 \pm 1,31) \mathrm{nmol} \mathrm{mL}^{-1}\right.$ prema $\left.(3,08 \pm 0,56) \mathrm{nmol} \mathrm{mL}^{-1}\right]$. Značajne su promjene također zamijećene u smanjenim razinama glutationa i njihovoj oksidaciji. Snažna povezanost razina olova u krvi s pokazateljima oksidacijskoga stresa upućuje na to da u osoba s niskom razinom izloženosti olovu iz okoliša kod razmatranja patogeneze bolesti povezane s olovom u obzir valja uzeti oksidacijski stres.

KLJUČNE RIJEČI: boje, cinkou protoporfirin, katalaza, lipidna peroksidacija, olovo u krui, superoksid dismutaza, toksičnost olova

\section{CORRESPONDING AUTHOR:}

Abbas Ali Mahdi, PhD

National Referral Centre for Lead Poisoning

Department of Biochemistry, C.S.M. Medical University

Lucknow 226003, Uttar Pradesh, India

E-mail:mahdiaa@rediffmail.com 